\begin{tabular}{|c|c|c|}
\hline & Int.J.Curr.Microbiol.App.Sci (2021) 10(09): 351-356 & \multirow{4}{*}{ 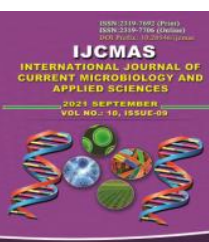 } \\
\hline & \multirow{4}{*}{$\begin{array}{l}\text { International Journal of Current Microbiology and Applied Sciences } \\
\text { ISSN: 2319-7706 Volume } 10 \text { Number } 09 \text { (2021) } \\
\text { Journal homepage: http://www.ijcmas.com }\end{array}$} & \\
\hline & & \\
\hline EXCELLENT & & \\
\hline PUBLISHERS & & www.ijemas.com \\
\hline
\end{tabular}

\title{
A Study on the Extent of Knowledge Gained and Adoption of Bio-Fertilizers and Bio-Pesticides by the Crop Growers of Keonjhar District in Odisha
}

\author{
Isha Anindita Sahoo ${ }^{*}$, Bibudha Parasar ${ }^{1}$ and Swatee Prangya ${ }^{2}$ \\ ${ }^{1}$ Department of Agricultural Extension and Communication, Institute of Agricultural Sciences, \\ Siksha 'O' Anusandhan (Deemed to be University), Bhubaneswar-751003, Odisha, India \\ ${ }^{2}$ Department of Social Science, ICAR-National Rice Research Institute, Cuttack-753006, \\ Odisha, India \\ *Corresponding author
}

Keywords

Knowledge gained, Adoption,

Bio-fertilizers, Bio-pesticides

Article Info

Accepted:

15 August 2021

Available Online:

10 September 2021
The study entitled "A study on the Extent of Knowledge Gained and Adoption of Bio fertilizers and bio pesticides by the Crop Growers of Keonjhar District in Odisha" was undertaken in 2020. For the purpose, ex-post-facto research designed was followed with snow-ball sampling technique for selection of respondents, random sampling technique for selection of villages and purposive sampling method was followed for selection of panchayat, block as well as the district, where 80 no. of respondents were selected for the purpose of the study. Data were collected with the help of interview schedule and the collected data were analyzed with the help of statistical measures like frequency, percentage, mean, standard deviation, correlation co-efficient for flawless interpretation and drawing correct conclusion against the objectives set for the study. The major findings of the study revealed that $(67.5 \%)$ i.e. majority of the respondents are at medium level of knowledge gain followed by (20\%) with high level and only $(12.5 \%)$ are at lower level of knowledge with regard of bio-fertilizers and biopesticides. The next part, level of adoption of respondents with regard to bio-fertilizer and bio-pesticides which was assessed and it was found that majority to the extent of (77.5\%) are at medium level of adoption in the context of bio-fertilizers whereas again majority of the respondent to the extent of (67.5\%) are at medium level of adoption when bio-pesticides are concerned.

\section{Introduction}

Global warming is one of the important issues in present scenario which is faced by people throughout the world. This is the resultant of increased population, environment pollution and increased usage of chemical fertilizer and pesticides for crop production. Agriculture has very important role in food security, economic growth and environment sustainability. 
Chemical fertilizer and pesticides usage is increasing day by day which leads to environment pollution viz., air pollution, soil pollution, water pollution where deep water reservoirs and water table has been contaminated which will cause significant health problems for human and unsustainable crop production. Henceforth, Bio-fertilizers and bio-pesticides found to be one of the viable options for sustained agriculture through organic farming under present climate change which posses lower cost and will not affect soil and environment as well as ecological balance is not disturbed.

Agriculture production depends on availability and use of quality and quantity of farm inputs. Use of bio-fertilizers and bio-pesticides have a supplementary nutritive role in productivity, are eco friendly, cost effective and enhance the soil fertility status. Bio-fertilizer is a substance which contains living microorganisms which, when applied to seeds, plant surfaces or soil, colonize the rhizosphere or the interior of the plant and promotes growth by increasing the supply or availability of primary nutrients to the host plant. Biopesticides (also known as biological pesticides) are certain types of pesticides derived from such natural materials such as animals, plants, bacteria, and certain minerals. Bio-pesticides generally affect only the target pest and closely related organisms, in contrast to broad spectrum, conventional pesticides.

In Indian situation, majority of the farmers with small land holdings, using bio-fertilizers in combination with chemical fertilizers and organic manures tender a higher opportunity for the farmers but bio-fertilizers and biopesticides were applied appropriately at the right time in, right ways, by the respondent farmers which leads to increase the crop production with low cost and with optimum benefit is just possible to harness full dividends from the situation. (Bokar and
Bhople 2002) in their study on bio-fertilizers farmer attitude and adoption observed that majority of the farmers (84.00 percent) belonged to moderate level of knowledge about different kinds of bio-fertilizers and their associate practices, about one tenth of them were adequately equipped with the knowledge about bio-fertilizer and appeared in high knowledge category. So, in the present context, the research problem is lack of information on adoption and knowledge gain of bio fertilizers and bio-pesticides by the farmers of Keonjhar district and the purpose of research is to measure the adoption and knowledge level of bio-fertilizers and biopesticides with the research questions as what are the factors which influence adoption or cause non-adoption / discontinuance of biofertilizers and bio-pesticides (biocides) in Keonjhar district.

Thus it is in the above context and background, the present study was undertaken with following specific objectives.

To measure the extent of knowledge gained with respect to selected bio fertilizers and bio pesticides by the respondent crop growers in the study area.

To study the adoption of selected bio fertilizers and bio pesticides by the respondent crop growers in the study area

\section{Materials and Methods}

The study was conducted purposively in Keonjhar disitrict of Odisha. Keonjhar district comprises of 13 no. of blocks out of which two blocks namely Keonjhar sadar and Harichandanpur were selected purposively as more no. of crop growers and non-tribal farmers are concentrated in these areas. A list of farmers from eight selected villages who used recommended bio-fertilizers and biopesticides on various crops were selected. 
From these villages 80 numbers of respondent crop growers were selected. Snow ball sampling techniques was followed for selecting the respondents from selected villages where villages were selected randomly. An adoption index was developed to know the adoption level of the respondents. A village wise list beneficiary was prepared with the help of information obtained from Krishi Vigyan Kendra Keonjhar. An ex-postfacto research design was followed for conducting the field study in order to collect data against the objectives set for the study. The interview schedule, it was pretested at random with $10 \%$ of the sample respondents. The data were collected with the help of structured interview schedule. Appropriate statistical analysis was done with the help of various statistical measures like frequency, percentage, mean, standard deviation, correlation co-efficient.

\section{Results and Discussion}

It is revealed from the above table no. 1 that majority of the respondents to the tune of $67.5 \%$ possess medium level of knowledge with regard to both bio- fertilizers and biopesticides. However only $20 \%$ respondents do possess high level of knowledge about the said products followed by $12.5 \%$ respondents with low level of knowledge. This might be due to the fact that the very technologies particularly in its hardware dimensions as well as to some extent in its software dimensions were not that very complex or difficult to understand and use, as perceived by the respondent farmers of the study area. The highest level of knowledge was available only with few chunk of the respondent farmers who possess awareness knowledge as well as how to do type of knowledge and in addition to the principle knowledge to some extent when assessed with the help of appropriate questions to find out the level of their knowledge. Through low level of knowledge as possessed by only small percentage of crop growers might be due to the reason linked with their skeptic attitude as a gesture of laggard among the categories of adopters

It is observed from the above table no.2, observed that majority of the respondent farmers are at medium level of adoption to the extent of $(77.5 \%)$ followed by $(12.5 \%)$ of them are at low level of adoption whereas only $(10 \%)$ do have high level of adoption behavior with regard to the bio-fertilizers in the study area. Similar findings were reported by (Naruka 2000) and (Borkar et al, M. M., G. D. Chothe and Lanjewar A. D. 2000) reported that majority of the farmer's medium level of adoption of bio-fertilizers. The reasons which may be attributed for medium level of adoption behaviour shown by majority of the respondents are:

The public extension system is saturated with promotion of chemical fertilizers as well as motivating farmers to use more such fertilizers for getting more yields from the crops which they produced.

The monitoring and supervision on the part of grass roots level extension functionaries both of the state govt. as well as of State Agricultural University (SAU) through its extension outfit like KVK through field agent or Krushaksathi or any contact/progressive farmers are very much lacking as they confined their roles and responsibility only to one instance or may be one or two more instance as per their sweet will, pleasure and off course comfort and conveniency for which majority of the farmers are at their liberty to use it fully, partially or reject the idea out rightly without giving any second thought. This is because there is nobody to remind them or to check their behaviour when they are in a mood to incorporate bio-fertilizers in their package of practices of the crops they prefer to grow. 
Table.1 Knowledge level of respondents of Bio-fertilizers and Bio- pesticides

\begin{tabular}{|c|c|c|c|}
\hline \multicolumn{2}{|c|}{ Level of Knowledge } & Frequency & $\%$ \\
\hline Sl.No. & Low $<($ mean-1SD $)$ & 10 & $\mathbf{1 2 . 5}$ \\
\hline $\mathbf{1}$ & Medium $($ Between mean+1SD and mean-1SD) & 54 & $\mathbf{6 7 . 5}$ \\
\hline $\mathbf{2}$ & High $>($ mean+1SD) & $\mathbf{1 6}$ & $\mathbf{2 0}$ \\
\hline
\end{tabular}

$(\mathrm{Mean}=25.5, \mathrm{SD}=2.942)$

Table.2 Respondents' Level Adoption of Bio-fertilizers

\begin{tabular}{|c|c|c|c|}
\hline \multicolumn{5}{|c|}{$(\mathrm{n}=80)$} \\
\hline SI.No. & Level of Adoption & Frequency & \% \\
\hline $\mathbf{1}$ & Low < (mean-1SD) & 10 & $\mathbf{1 2 . 5}$ \\
\hline $\mathbf{2}$ & Medium $($ Between mean+1SD and mean-1SD) & 62 & $\mathbf{7 7 . 5}$ \\
\hline $\mathbf{3}$ & High $>($ mean+1SD $)$ & $\mathbf{8}$ & $\mathbf{1 0}$ \\
\hline
\end{tabular}

$(\mathrm{Mean}=15.53, \mathrm{SD}=3.158)$

Table.3 Respondents' Level of Adoption of Bio-pesticides

\begin{tabular}{|c|c|c|c|}
\hline \multicolumn{4}{|c|}{$(\mathrm{n}=80)$} \\
\hline SI.No. & Level of Adoption & Frequency & $\%$ \\
\hline $\mathbf{1}$ & Low < (mean-1SD) & 10 & $\mathbf{1 2 . 5}$ \\
\hline $\mathbf{2}$ & Medium (Between mean+1SD and mean-1SD) & 56 & $\mathbf{6 7 . 5}$ \\
\hline $\mathbf{3}$ & High > (mean+1SD) & $\mathbf{1 4}$ & $\mathbf{1 7 . 5}$ \\
\hline
\end{tabular}

$(\mathrm{Mean}=9.9, \mathrm{SD}=1.84)$

It is also interesting to note that almost equal percentage of crop growers are having high as well as low level of adoption. According to (Ravindra Kumar and Dipak Kumar Bose. 2020) $33.34 \%$ had lowest level of adoption regarding bio-fertilizers. This may be due to the fact that in the study area, there are also farmers who are highly innovative in their thought, approach and farming behaviour and also another category who takes time to move from awareness stage to adoption stage through interest, evaluation and trial stage in between becoming impatient and losing their interest and finally from courtesy shake they get involved in the process for which the expected level of adoption behaviour is not seen with them.

As evident from the above table no. 3 it is found that about $67.5 \%$ of the respondent farmers are at medium level of adoption followed by high level and low level with
$17.5 \%$ and $12.5 \%$ of respondent farmers respectively. Similar finding is reported by (Chapke, R. 2000).This was again a manifestation of adoption behaviour of the respondent farmers which may be viewed as a spillover effect or hangover behaviour of the respondents when they were using or adopting bio-fertilizers which was very much helpful in reinforcing the compatibility character of the bio-pesticides with that of their past experience of the potential adopters or users who experienced the effect of bio-fertilizers in earlier occasion and assess bio-pesticides on same tone, mode, and spirit.

As both bio-fertilizer and bio-pesticides adoption behaviour shown uniform pattern we may safely conclude that the level can be up only when more concerted efforts will be made by the extension functionaries, input dealers and farmers themselves to harness better evident by using these bio products in 
their situations. Furthermore, the diffusion and adoption of bio-fertilizers and bio-pesticides can also be facilitated through organizing good number of training programmes both oncampus and off-campus mode with assured market support in the form of input marketing (recommended bio-fertilizers and biopesticides) and output marketing (the very organic products).

\section{Recommendations}

The prospective demand for bio-fertilizers and bio-pesticides are more; the real demand of use of bio-fertilizers and bio-pesticides are low from the respondents as they lack awareness of use of bio-fertilizers and biopesticides, knowledge on quality of the product by the use of bio-fertilizer, negative attitude towards use of bio-fertilizers and biopesticides give more emphasize. As a result of awareness programmes and promotional activities conducted by the Government and other related agencies the proportion of farmers using bio-fertilizers and bio-pesticides have increased. According to (Chavan Vishal Shivajirao 2015) revealed that majority of farmers suggested that use of bio-fertilizer is increased when bio-fertilizers are supplied for free of cost and also when availability of biofertilizer in village level. But the adoption and knowledge level regarding these bio-fertilizers and bio-pesticides are not uniformly spread across the farmer respondents, It was concluded that majority of the respondents are at medium level of adoption with regard to bio-fertilizers and bio-pesticides, in order to enhance their level of adoption through enhancing extent of adoption on the basis of area, population, as well as innovation basis, govt. machineries through public extension system, agricultural extension activities show be encouraged with emphasis. There for Govt. conducting more number of training programmes and demonstrations on use of bio products for farmer respondents will help to gain knowledge properly and more adoption of the bio-fertilizers and bio-pesticides in their field.

\section{References}

Bhople and Borker (2002). Bio-fertilizers farmer attitude and adoption. Agricultural Extension. Review, 14: 21-22.

Borkar, M. M., G. D. Chothe ad Lanjewar A. D. (2000). Characteristics of farmers influencing their Knowledge about use of bio-fertilizers. Mah/ J. Ext. Edu., 19: 5963.

Chapke, R. (2000). Knowledge and adoption of farmers about bio control measures". Maharashtra Journal of Ext. Edu. Vol. XIX: 41-47.

Chavan Vishal Shivajirao. (2015). "Extent of Knowledge and adoption of bio- fertilizers use by the farmers". M.Sc (Agri) Thesis. Mahatma Phule Krishi Vidyapeeth, Rahuri, Ahmednagar, Maharastra

Dutt K. Sunil, rajeswar jakkawad, rajendra. C. Sawant and S. B. Pawar. (2016). Extent of Participation and Knowledge Level of the Beneficiaries about various Aspect of biofertilizer and Benefits availed. Journal of Trends in Biosciences10 (24).

Naruka, P. S. (2000). A study on adoption of biofertilizer in Jaipur district of Rajasthan. M.Sc. (Ag.) Thesis RAU, Bikaner Campus Jobner.

Ravindra Kumar and Dipak Kumar Bose. (2020). A study on the extent of adoption of bio fertilizers by the farmers in Etawah District of Uttarpradesh. Int.J.Curr.Microbiol.App.Sci.9 (11): 28532857.

Roop Kumar, R. N, Yadav, Monoj Kumar, Amit Kumar Mishra, Akshay Kumar and Kshitij Parmar. (2017). Impact of Knowledge on Adoption of Integrated Pest Management Practices by Sugarcane Growers. Int.J.Curr.Microbiol.App.Sci.6 (3): 348354. 


\section{How to cite this article:}

Isha Anindita Sahoo, Bibudha Parasar and Swatee Prangya. 2021. A Study on the Extent of Knowledge Gained and Adoption of Bio-Fertilizers and Bio-Pesticides by the Crop Growers of Keonjhar District in Odisha. Int.J.Curr.Microbiol.App.Sci. 10(09): 351-356.

doi: https://doi.org/10.20546/ijcmas.2021.1009.040 